\title{
BMJ Open Effectiveness of individualised nutritional care plans to reduce malnutrition during hospitalisation and up to 3 months post-discharge: a systematic scoping review
}

Kari Ingstad (D) , ${ }^{1}$ Lisbeth Uhrenfeldt, ${ }^{2}$ Ingjerd Gåre Kymre, ${ }^{2}$ Conni Skrubbeltrang, ${ }^{3}$ Preben Pedersen ${ }^{4}$

To cite: Ingstad $K$, Uhrenfeldt L, Kymre IG, et al. Effectiveness of individualised nutritional care plans to reduce malnutrition during hospitalisation and up to 3 months postdischarge: a systematic scoping review. BMJ Open 2020;10:e040439. doi:10.1136/ bmjopen-2020-040439

- Prepublication history and additional materials for this paper are available online. To view these files, please visit the journal online (http://dx.doi org/10.1136/bmjopen-2020040439).

Received 13 May 2020 Revised 01 September 2020 Accepted 13 October 2020

Check for updates

(c) Author(s) (or their employer(s)) 2020. Re-use permitted under CC BY-NC. No commercial re-use. See rights and permissions. Published by BMJ.

For numbered affiliations see end of article.

\section{Correspondence to}

Professor Kari Ingstad, Faculty of Nursing and Health Sciences, Nord University, Levanger, Norway; kari.ingstad@nord.no

\section{ABSTRACT}

Objectives The prevalence of malnutrition after hospitalisation is reported to be $20 \%-45 \%$, which may lead to adverse outcomes, as malnutrition increases the risk of complications, morbidity, mortality and loss of function. Improving the quality of nutritional treatment in hospitals and post-discharge is necessary, as hospital stays tend to be short. We aimed to identify and map studies that assess the effectiveness of individualised nutritional care plans to reduce malnutrition during hospitalisation and for the first 3 months post-discharge.

Design This was a systematic scoping review. Methods We systematically searched for all types of studies in the following databases: EMBASE, MEDLINE via PubMed, and the Cumulative Index to Nursing and Allied Health Literature, with no restriction on data or publication language. We also reviewed the reference lists of the included studies. The abstracts and full articles were simultaneously screened by two independent reviewers. Differences of opinion were discussed among the two investigators, and a third reviewer assisted with the discussion until consensus was reached. Studies in which the patients received an individual nutritional care plan related to their hospital stay and were followed up post-discharge were included. We then conducted a thematic content analysis of the extracted literature.

Results Nine randomised controlled trial studies met the inclusion criteria: six were conducted in Scandinavian countries. All studies were mainly conducted among elderly patients (mean ages varied from 75 to 88 years). The review studies measured 10 different outcomes; the most common outcomes were nutritional status and readmission. Six studies reported one or more significant positive intervention effect. Inconsistent results were identified for four outcome variables.

Conclusions Individualised nutritional care plans and follow-up home visits might improve patients' nutritional status. However, there is need for a systematic review that assesses study quality and extends the time to 6 months post-discharge.

\section{Strengths and limitations of this study}

- This is the first scoping review to identify and map studies that assess the effectiveness of individualised nutritional care plans.

- The evidence obtained from the included studies may help guide nutritional practice and future research.

- There were no language restrictions in this review.

- The search strategy was created by the research team, which included an experienced medical librarian.

- Three months' follow-up time may be insufficient, especially for determining whether an intervention can reduce the risk of readmission or mortality rates.

\section{INTRODUCTION}

Hospitals worldwide struggle to prevent malnutrition, especially among hospitalised older adults. ${ }^{1-4}$ Studies have reported the prevalence of malnutrition to be $20 \%-45 \%$ at the time of discharge. ${ }^{5-7}$ Incomplete nutrition treatment may adversely impact patients' health outcomes, as malnutrition increases the risks of complications, loss of function, prolonged hospital stay, morbidity and mortality. ${ }^{6-12}$ Therefore, there is a need to improve the quality of nutritional treatment in hospitals.

Nutritional problems neither occur, nor are solved, overnight and caring for patients with multifaceted nutritional issues is considerably more complex than merely addressing a failure to eat. Providing nutritional care may include psychological, physical and social issues-such as dental problems, addiction, dementia, dysphagia, depression and loneliness-that affect patients' appetites and ability to eat. ${ }^{13}$ Cooperation and communication among healthcare providers 
are important to ensure that patients receive proper and coordinated nutritional treatment and care. ${ }^{14}$ Individualised care acknowledges the uniqueness of the individual, and may improve the quality of nutritional care in cases of complex nutritional problems. One randomised controlled trial (RCT) study indicated that individualised nutritional treatment improves energy intake and the activities of daily living (ADLs) of older patients who had an acute stroke with malnutrition risk, as compared with a standard care group. ${ }^{15}$

The average length of stay in hospitals has declined since 2000 in most countries. ${ }^{16}$ The average length of stay in hospitals due to all causes among the 36 member countries of the Organisation for Economic Co-operation and Development was approximately 8 days in $2015 .{ }^{16} 17$ Shorter hospital stays have led to an increased need for nutrition treatment post-discharge to promote improvement in nutritional status-for example, energy intake and body mass index-to prevent complications and readmission. ${ }^{18-20}$ However, lack of continuity in care and poor communication have been identified as important risk factors for malnutrition. ${ }^{142122}$

In 2012, a systematic review concluded that transitional care initialised in hospitals could yield positive outcomes among hospitalised adult patients. ${ }^{23}$ Another study revealed that dietetic care in hospitals was the most potent predictor of post-hospital care, although dietetic post-discharge care was conducted for only a few patients. ${ }^{24}$ Early and prolonged nutrition intervention can lead to better nutrition status and reduce length of hospital stays. ${ }^{25}$ Hospital-initiated care plans with follow-up by qualified healthcare providers post-discharge may be effective in improving nutritional status as well as reducing complications and decreasing readmission rates among aged patients. ${ }^{26}{ }^{27}$ The advantages of nutritional intervention initiated during hospital stay may be missed if continuity of care is not adequately addressed when patients are discharged.

Therefore, individualised care plans with follow-ups could be an effective approach to improve nutritional care and may reduce malnutrition. This scoping review, unlike a previous systematic review, ${ }^{22}$ focused on individualised nutritional care plans and not individualised dietary counselling. We aimed to bring new insight concerning how individualised nutritional care plans with follow-ups can reduce malnutrition.

Individualised care plans are developed based on a detailed individual assessment of patients' nutritional needs, conditions and desires. ${ }^{28} 29$ The individualised care plan includes patients' nutritional status, individual nutritional treatment measures, dietary intake and requirements. The plan includes appropriate nutritional interventions, which are evaluated and adjusted according to changes in the patient's situation and condition. ${ }^{26}$ Information about adjustment of physical, psychological and social factors that hinder appropriate dietary intake can also be added. ${ }^{29}$ A multidisciplinary team involved in the patient's care design the nutritional care plan. This may include recommendations provided by dietitians, nurses, occupational therapists, midwives and the medical team; however, the recommendations are not limited to those from these professions. ${ }^{30}$ A nutrition care plan contains clearly documented nutrition interventions to achieve defined goals of treatment; these plans are revised continuously to assess their effectiveness and are adjusted, if needed, until the treatment goals are obtained. ${ }^{28-30}$

There is a need to map the research evidence on this topic. Systematic scoping reviews can be very useful for mapping research evidence and are frequently used to identify research gaps, clarify key concepts, and report on the types of evidence that address and inform practice in a research field. ${ }^{3132}$

\section{Aims}

This study aimed to identify and map studies that assess the effectiveness of individualised nutritional care plans with follow-ups to reduce malnutrition during hospital stay and for the first 3 months post-discharge from the hospital. The particular research questions to be addressed were:

1. What types of individualised nutritional care plan interventions are addressed in the literature?

2. Which populations are studied?

3 . What outcomes are measured in the studies?

4. Are these interventions effective?

5. If these interventions are effective, in what way are they effective?

\section{METHODS}

A systematic scoping review methodology was employed, based on an a priori published protocol (see online supplemental file 1). ${ }^{33}$ Briefly, this scoping review was guided by Arksey and O'Malley's framework, ${ }^{34}$ which was extended by Levac et $a l^{35}$ and the Joanna Briggs Institute. ${ }^{36}$ It adhered to the Extension for Scoping Reviews of Preferred Reporting Items for Systematic Reviews and Meta-Analyses: Checklist and Explanation. ${ }^{37}$

\section{Search strategy}

The search strategy was created by the research team, which included an experienced medical librarian. As recommended by the Joanna Briggs Institute, ${ }^{36}$ a threestep search strategy was used in this review and published in the protocol. ${ }^{33}$ Literature search strategies were developed using medical subject headings browser and text words related to nutrition, individualised care plans and transitional care. ${ }^{33}$ EMBASE, MEDLINE via PubMed, and the Cumulative Index to Nursing and Allied Health Literature were searched in April 2019, and the search was updated in January 2020. Searches were performed with no language and date of publication restrictions. The databases were searched from the time of database inception. All reference lists of included articles were searched to identify additional studies. The reference lists of related reviews were also searched. 
The criteria for inclusion in this study were adult patients of both sexes; aged $\geq 18$ years; who received an individualised nutritional care plan. The nutritional care plan had to be written, obtained related to the patient's hospital stay, and followed-up in the next 3 months postdischarge from the hospital surgical, medical or rehabilitation unit. There were no further requirements for the plans. All outcomes measured in the studies were of interest. This review considered studies involving patients who were discharged from any hospital, for up to 3 months post-discharge. In addition, we included studies lasting longer than 3 months if they reported results for up to 3 months post-discharge; when interventions lasted for more than 3 months, we included results only up to 3 months post-discharge.

\section{Study selection and data abstraction}

References from the literature search were imported to Covidence, an internet-based software program that facilitates screening, data extraction and collaboration among reviewers. The first and last authors independently screened the abstracts and titles according to the inclusion and exclusion criteria. The same two investigators independently assessed the full-text reports retrieved for potential inclusion. Differences of opinion were discussed, and a third reviewer assisted with discussions until consensus was reached. All data were independently charted from the included papers by the first and last authors. A standardised charting form was developed and aided in categorisation of the data.

This scoping review provides a narrative account of findings from the existing literature through thematic content analysis of the extracted literature. Multiple outputs from the same trial are reported according to the manner in which the original article reported them. Study quality assessment was not relevant, as the objective of a scoping review is to identify gaps in the literature and highlight future areas for systematic review. ${ }^{34} 35$

\section{RESULTS}

The study flow diagram (figure 1) indicates the 4490 citations resulting from the literature search. Eighty-five potentially eligible articles remained and were retrieved in full text, of which 76 were excluded based on the inclusion and exclusion criteria. This resulted in a total of nine RCTs that were included in this review. ${ }^{19252738-43}$ All types of study designs were searched; however, only these nine RCTs met all inclusion and exclusion criteria. Reasons for article exclusion were primarily due to inappropriate study population (ie, no transition from the hospital); other reasons included inappropriate intervention (ie, the study did not include an individualised nutritional care plan or the study did not entail any post-discharge follow-up). The intervention in two studies lasted for more than 3 months ${ }^{40}{ }^{43}$; only the results up to 3 months were included in this study.

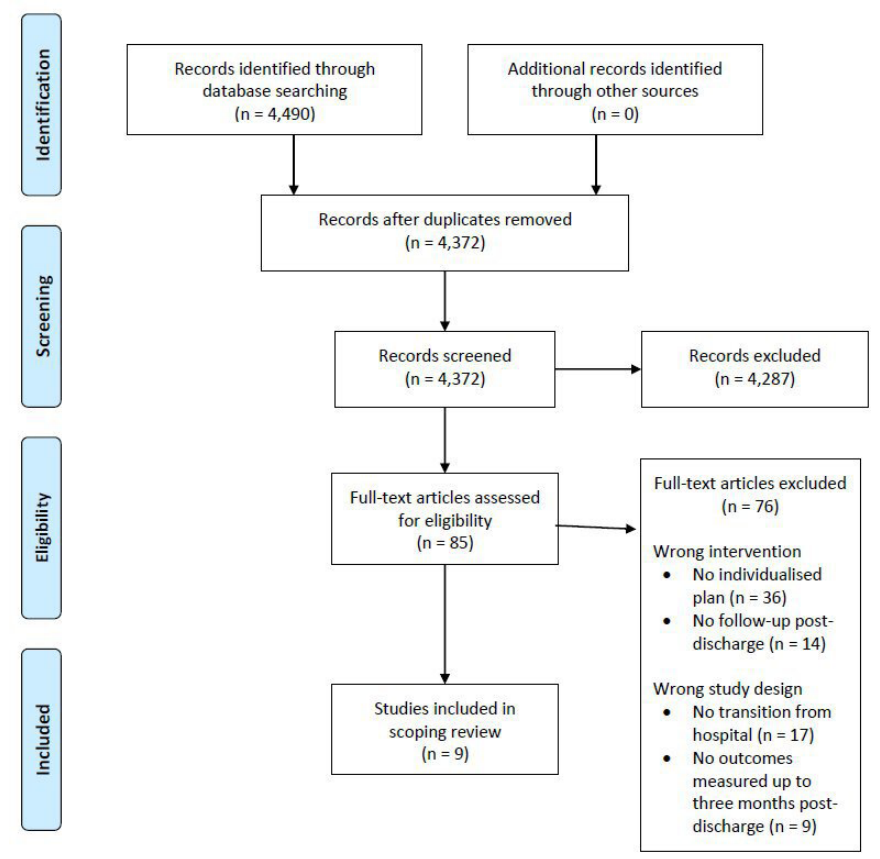

Figure 1 Study flow diagram (http://www.prisma-statement. org) for the scoping review process, from Moher et al (2009). ${ }^{46}$

Here, the data from the studies are presented and discussed concerning the overall concepts/components related to the effectiveness of individualised nutritional care plans for adults during hospital stay and the first 3 months post-discharge. The results are presented in full in tables 1-3.

\section{Characteristics of the included studies}

Five of the included studies were from Denmark, ${ }^{19} 27384142$ one was from Norway, ${ }^{39}$ one was from Israel, ${ }^{40}$ one was from Australia ${ }^{25}$ and one was from Taiwan. ${ }^{43}$ The studies were conducted between 2011 and 2019. Sample sizes ranged from 71 to 259, and participants' mean ages varied from 75 to 88 years. Pedersen et $a l^{27}$ published two articles, both originating from the same trial. Beck et $a l^{1938}$ also published two articles, originating from different trials. Eight studies involved patients aged $>60$ years, and one study included patients aged $\geq 18$ years. ${ }^{39}$ The mean age across all nine studies was $\geq 75$ years.

\section{Nutritional care plan intervention}

The individual nutritional care plans had a variety of characteristics and were performed by different professions in different settings. The plan was designed either in the hospital ${ }^{25}$ 27 39-43 or after the patient was discharged home. ${ }^{19} 39$ The care plan was designed by a clinical nutritionist, ${ }^{39}$ dietitian, ${ }^{19} 38404243$ clinical nurse specialist ${ }^{2741}$ or ward dietitian, ${ }^{25}$ in all cases together with the patient. The studies entailed two, ${ }^{1925}$ three $^{2740-42}$ or four ${ }^{38} 39$ follow-up visits. One study did not report the number of follow-ups. ${ }^{43}$ The visits were performed either by home visit, ${ }^{19} 384042$ a telephone call, ${ }^{25}$ both home visit and telephone call, ${ }^{39}$ or a home visit for intervention group 1 and a telephone 
Table 1 Description of included studies $(\mathrm{N}=9)$, ordered alphabetically

\begin{tabular}{|c|c|c|c|}
\hline \multirow{3}{*}{$\begin{array}{l}\text { Study and } \\
\text { country }\end{array}$} & \multirow[b]{3}{*}{ Aim } & \multirow[b]{3}{*}{ Study design } & (a) Population \\
\hline & & & (b) Number \\
\hline & & & (c) Setting (recruitment) \\
\hline \multirow[t]{3}{*}{$\begin{array}{l}1 . \\
\text { Andersson } \\
\text { et }\left.a\right|^{39} \\
\text { Norway }\end{array}$} & \multirow{3}{*}{$\begin{array}{l}\text { To test if tailor-made nutritional } \\
\text { counselling mediated via home visits } \\
\text { and phone calls could reduce weight } \\
\text { loss among undernourished patients } \\
\text { and those at risk of disease-related } \\
\text { malnutrition } 3 \text { months post-discharge } \\
\text { from a specialised rehabilitation } \\
\text { care centre. Additionally, to examine } \\
\text { quality of life and appetite among } \\
\text { the participating patients. }\end{array}$} & \multirow[t]{3}{*}{ Open, RCT } & $\begin{array}{l}\text { (a) Rehabilitation patients (aged } \geq 18 \text { years) } \\
\text { undernourished/at risk of disease-related } \\
\text { malnutrition. Geographical restrictions. Mean } \\
\text { age: } I G=75 \text { years; } C G=76 \text { years. }\end{array}$ \\
\hline & & & (b) $\mathrm{N}=100$ : IG, $\mathrm{n}=52 ; \mathrm{CG}, \mathrm{n}=48$. \\
\hline & & & $\begin{array}{l}\text { (c) Health and rehabilitation institution, patien } \\
\text { with musculoskeletal disorders, cancer, } \\
\text { lymphoedema, cardiovascular disease, chror } \\
\text { pulmonary disease, stroke, neurodegenerativ } \\
\text { diseases, and patients having undergone } \\
\text { abdominal and orthopaedic surgery. }\end{array}$ \\
\hline \multirow[t]{3}{*}{$\begin{array}{l}\text { 2. Beck } \\
\text { et } a l^{13} \\
\text { Denmark }\end{array}$} & \multirow{3}{*}{$\begin{array}{l}\text { To assess the additional benefits of } \\
\text { individualised nutritional care plan } \\
\text { and counselling by a registered } \\
\text { dietitian in geriatric patients' home } \\
\text { post-discharge from hospital, in } \\
\text { relation to risk of readmissions, } \\
\text { functional status, nutritional status, } \\
\text { use of social services and mortality. }\end{array}$} & \multirow[t]{3}{*}{$\mathrm{RCT}$} & $\begin{array}{l}\text { (a) Geriatric medical patients (aged } \geq 65 \text { years } \\
\text { nutritional risk. Geographical restrictions. Me } \\
\text { age: } I G=82 \text { years, } C G=81 \text { years. }\end{array}$ \\
\hline & & & (b) $N=152$ : IG, $n=73 ; C G, n=79$. \\
\hline & & & $\begin{array}{l}\text { (c) Department of Geriatric Medicine, Herlev } \\
\text { University Hospital, Denmark. }\end{array}$ \\
\hline
\end{tabular}

$\begin{array}{ll}\text { 3. Beck } & \text { To test whether adding a dietitian } \\ \text { et } \text { a }^{19} & \text { to a discharge liaison team post- } \\ \text { Denmark } & \text { discharge of geriatric patients } \\ & \text { improves nutritional status, muscle } \\ & \text { strength and patient-relevant } \\ & \text { outcomes. }\end{array}$

4. Feldblum To test the hypothesis that et $a l^{40}$ Israel individualised nutritional treatment during and post-discharge from acute hospitalisation will reduce mortality and improve nutritional outcomes.
$\mathrm{RCT}$

(a) Geriatric patients (aged $\geq 70$ years) at nutritional risk. Median age: $I G=85$ years, $C G=85$ years.

(b) $N=71$ : IG, $n=34$; $C G, n=37$.

(c) Patients hospitalised at Department of Geriatric Medicine and Orthopaedic Surgery at Herlev University Hospital, Denmark.

RCT

(a) Hospitalised adults (aged $\geq 65$ years) at nutritional risk. Mean age: $I G=75$ years, $C G 1=75$ years, $C G 2=75$ years.

(b) N=259: IG1 (hospital and community treatment), $n=78$; CG1 (hospital treatment), $\mathrm{n}=73$; CG2 (traditional care), $\mathrm{n}=108$.

(c) Department of Internal Medicine, Soroka University Medical Centre, Israel.

$\begin{array}{ll}\text { 5. Pedersen } & \text { To determine the effects of two } \\ \text { et } a l^{41} & \text { nutritional follow-up interventions } \\ \text { Denmark } & \text { regarding preventing short-term } \\ & \text { deterioration in activities of daily } \\ & \text { living (ADLs), and to compare } \\ & \text { their effects on physical function, } \\ & \text { emotional health and health-related } \\ & \text { quality of life. }\end{array}$

6. Pedersen To compare the effects of two et $a^{27} \quad$ individualised nutritional followDenmark up intervention strategies (home visit of telephone consultation) with no follow-up, regarding acute readmission to hospital at two points $=30$ and 90 days postdischarge from hospital.

$\begin{array}{ll}\text { 7. Sharma } & \begin{array}{l}\text { To compare usual care with an } \\ \text { et } \mathrm{a}^{25}\end{array} \\ \text { individualised nutrition screening and } \\ \text { Australia } & \begin{array}{l}\text { intervention, which included dietary } \\ \text { modification and oral nutrition } \\ \text { supplements, initiated early during } \\ \text { hospitalisation and extending for a } \\ \text { period of } 3 \text { months post-discharge } \\ \text { with monthly telehealth follow-up. }\end{array}\end{array}$

\section{RCT (a) Geriatric patients (aged $\geq 75$ years)} malnourished/at risk of malnutrition and living at home alone. Mean age: IG1=86 years, IG2=86

(b) N=208: IG1, n=73 (home visits); IG2, n=68 (telephone consultations); $\mathrm{CG}=67$.

(c) Department of Geriatrics, Aarhus University Hospital, Denmark.

\section{$\mathrm{RCT}$}

(a) Geriatric patients (aged $\geq 75$ years) malnourished/at risk of malnutrition and living at home alone. Mean age: $I G 1=86$ years, $I G 2=86$ years, $C G=86$ years.

(b) N=208: IG1, $\mathrm{n}=73$ (home visits); IG2, $\mathrm{n}=68$ (telephone consultations); CG, $\mathrm{n}=67$.

(c) Department of Geriatrics, Aarhus University Hospital, Denmark.

(a) Malnourished patients (aged $\geq 60$ years) with geographical restrictions. Mean age: $I G=82$ years, $C G=82$ years

(b) $N=148$ : IG, $n=78$; CG, $n=70$.

(c) General Medicine Department of Flinders Medical Centre, Australia. years, $C G=86$ years.

\section{Authors' conclusion}

Individually adapted nutritional counselling did not improve body mass among elderly patients 3 months post-discharge from a rehabilitation institution. Neither quality of life nor appetite measures were improved. Possibly nutritional counselling should be accompanied with nutritional supplementation to be effective in this vulnerable group of elderly adults.

Follow-up home visits with

registered dietitians had a positive effect on the functional and nutritional status of geriatric medical patients post-discharge.

The intervention had a positive effect on weight, energy and protein intake. 


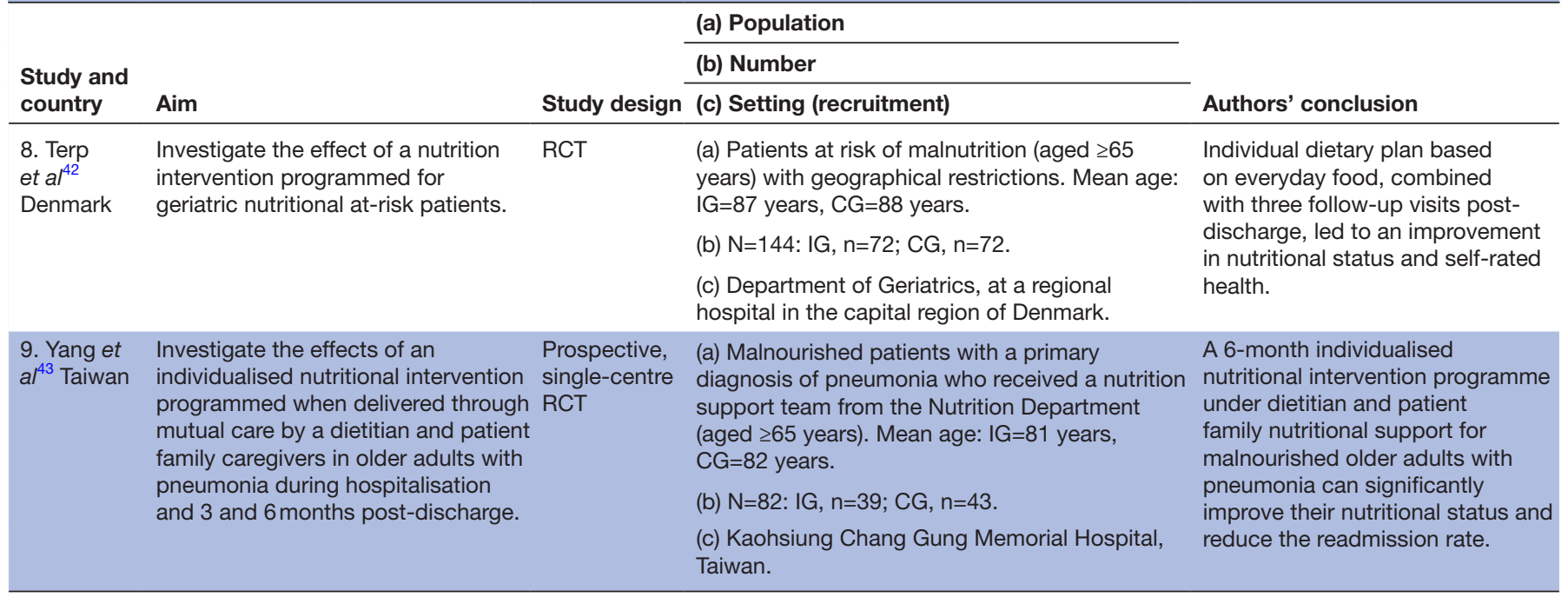

CG, control group; IG, intervention group; RCT, randomised controlled trial.

call for intervention group 2. ${ }^{27} 41$ The follow-ups were conducted by dietitians (sometimes together with municipality care/general practitioners), ${ }^{19} 25384043$ clinical dietitians, ${ }^{2741}$ or, in combination, municipality care and geriatric hospital nurses. ${ }^{42}$ One study ${ }^{39}$ did not report who was responsible for the follow-ups. The individualised care plans were all developed based on an individual assessment of patients' nutritional needs, conditions and desires. The main characteristics of the nutritional care plans are provided in table 2 .

\section{Outcomes and effect of interventions}

The studies measured 10 different outcomes (table 3). Eight studies measured nutritional status, ${ }^{19}{ }^{25}{ }^{38-43}$ such as appetite, body mass index, dietary intake and weight. Five studies measured re/hospitalisation ${ }^{19} 25273842$ or both rehospitalisation and changes in length of hospital stay. Four studies measured ADLs, ${ }^{19} 384142$ including feeding, transfer, grooming, using the toilet, bathing, walking, climbing stairs, dressing, and bowel and bladder control. Four studies measured physical performance ${ }^{19384142}$; for example, mobility, gait speed, muscle strength, handgrip strength, chair-stand, disability, and tiredness in daily activities, rehabilitation capacity and Cumulated Ambulation Score. Quality of life was measured in four studies. ${ }^{19253941}$ Two studies measured the need for social services ${ }^{19} 38$ need for home care, home nursing and meals-on-wheels. One study measured depression, ${ }^{41}$ one study measured complications during hospitalisation ${ }^{25}$ and one study measured self-rated health. ${ }^{42}$ Three studies measured one outcome up to 3 months post-discharge, ${ }^{27} 4043$ one study measured two outcomes ${ }^{39}$ and five studies measured $\geq$ four outcomes. ${ }^{1925384142}$ Seven studies ${ }^{1925273841-43}$ reported one or more significant positive effects of the intervention. The effectiveness of the interventions is shown in table 3 .

\section{DISCUSSION}

To the best of our knowledge, this is the first scoping review to identify and map studies that assess the effectiveness of individualised nutritional care plans. The search strategy aimed to locate all study designs; however, only nine RCTs met the inclusion criteria. The dearth of studies on such a common topic may be due to several factors. Nutritional counselling may be more common than preparing nutritional care plans. Also, nutritional care plans may be prepared in the hospital but not followed up post-discharge, which was an inclusion criterion for this review.

All the studies mainly included geriatric patients at nutritional risk, and only one study focused on a particular diagnosis. ${ }^{43}$ All RCTs except one ${ }^{43}$ entailed samples that comprised mostly women. Four studies had geographical restrictions, ${ }^{2538} 3942$ which might have led to the exclusion of rural patients. Six of the nine included studies were performed in Scandinavian countries, ${ }^{19} 2738394142$ which might reflect the long tradition of focusing on personoriented care in Scandinavia. ${ }^{44}$ User participation and patient perspective are among the cornerstones of the Nordic model and approach to healthcare provision, ${ }^{45}$ which might lead to more individualised care in Scandinavia.

The reviewed studies revealed that individualised nutritional care plans were based on individual needs and requirements, although the content of the individualised plans somewhat differed. In addition, to meet patients' nutritional needs, the individualised nutritional plan might include/consider meals-onwheels $^{19273841}$; economic factors, such as inexpensive food sources and recipes ${ }^{40}$; and oral nutritional supplements (ONSs). ${ }^{19} 252738$ 40-42 Patients' nutritional problems and constraints are complex. Aged people are heterogeneous regarding health status, prognosis, nutritional needs, 
Table 2 Description of the individual nutritional care plans in the included studies and the follow-up post-discharge from hospital

\begin{tabular}{|c|c|c|}
\hline $\begin{array}{l}\text { Study and } \\
\text { country }\end{array}$ & $\begin{array}{l}\text { Design of individual } \\
\text { nutritional plan: (a) where, } \\
\text { (b) when and (c) who }\end{array}$ & $\begin{array}{l}\text { Individualised nutritional plan: (a) content and } \\
\text { (b) based on }\end{array}$ \\
\hline \multirow[t]{3}{*}{$\begin{array}{l}\text { 1. Andersson et } \\
a l^{39} \text { Norway }\end{array}$} & (a) Hospital & $\begin{array}{l}\text { (a) Nutritional status, nutrient requirements and } \\
\text { nutrient intake. }\end{array}$ \\
\hline & (b) Before discharge & $\begin{array}{l}\text { (b) Information regarding swallowing function, } \\
\text { bowel function, appetite, food preferences and } \\
\text { personal habits }\end{array}$ \\
\hline & (c) Clinical nutritionist & \\
\hline $\begin{array}{l}\text { 2. Beck et } a l^{18} \\
\text { Denmark }\end{array}$ & (a) Home & $\begin{array}{l}\text { (a) Estimated nutritional requirements, nutritional } \\
\text { rehabilitation goals, dietary counselling with } \\
\text { attention to nutritional risk factors, timing, size } \\
\text { and frequency of meals and meals-on-wheels (if } \\
\text { needed). }\end{array}$ \\
\hline
\end{tabular}
(b) 1 week post-discharge
(b) Standardised dietary interview

(b) Reviewing nutritional plan, dietary counselling, motivation and education and weight.

(c) Registered dietitian

\begin{tabular}{|c|c|}
\hline $\begin{array}{l}\text { 3. Beck et al }{ }^{19} \quad \text { (a) Home } \\
\text { Denmark }\end{array}$ & $\begin{array}{l}\text { (a) Estimated nutritional requirements and } \\
\text { nutritional rehabilitation goals. Specific focus } \\
\text { was on optimising the intake of protein and the } \\
\text { distribution of protein during the day. Providers } \\
\text { of meals-on-wheels were contacted if relevant to } \\
\text { change the meals delivered. }\end{array}$ \\
\hline
\end{tabular}

(b) The day of discharge $\quad$ (b) Individual nutritional assessment focusing on dietary intake, activity level and weight

(c) Two follow-up visits by registered dietitians, 3 follow-up visits by general practitioners and the last visit together
(a) Two home visits at 3 and 8 weeks post- discharge.

Oral

(a) Follow-up, (b) content in follow-up and

nutritional

(a) One home visit 4 weeks post-discharge. supplement Three telephone calls after 1,7 and 10 weeks.

No

(b) Nutritional counselling, patients' adherence to nutritional plan was assessed. Individual adjustment if needed.

c) Not reported

(a) Four follow-up visits at 1, 3 (×2) and 8 weeks Yes post-discharge.

(b) Reviewing the nutritional care plan, dietary counselling, motivation, education, monitoring participant weight and ensuring that energy and protein requirements were achieved.

(c) Dietitian

(c) Dietitian, the first visit together with the discharge liaison-team.

(a) Three home visits 1 week, 1 month and Yes

4. Feldblum et (a) Hospital $a l^{40}$ Israel (a) Individual treatment goals, recommendations for nutrient intake and anthropometrical and biochemical goals. The basic approach was to develop a dietary menu based on inexpensive food sources and recipes.

(b) Before discharge

(b) Nutritional assessment during the first home visit (c) Dietitian

5. Pedersen et $\quad$ (a) Hospital

(b) Before discharge

(c) Clinical nurse specialist (a) Three daily meals, three between-meal snacks, supplements and instructions for implementing the plan. Individual arrangements with the primary healthcare provider; for example, concerning nutritional support post-discharge, meal service, food delivery and home care to supply daily meals.

(b) Nutritional needs identified during hospital stay and tailored to the individual preferences and circumstances (b) Nutritional assessment including dietary intake, nutritional problems, food preferences and appetite status. During the second visit, the dietetic treatment was enforced and corrected as required by the patient and his or her caregivers. Family members or first-contact caregivers were also instructed, as necessary. During the last visit, patients and their caregivers received instructions on how to follow the recommended diet.

(c) Dietitian.

\section{(a) Three home visits or counselling over} telephone 1, 2 and 4 weeks post-discharge.

(b) Nutritional counselling, patients' adherence to nutritional plan was assessed, identify inhibiting and restraining elements, motivation and adjusting the nutrition plan if needed.

(c) Clinical dietitian, attended by the patients' daily home care provider. 
Table 2 Continued

\begin{tabular}{|c|c|c|c|c|}
\hline $\begin{array}{l}\text { Study and } \\
\text { country }\end{array}$ & $\begin{array}{l}\text { Design of individual } \\
\text { nutritional plan: (a) where, } \\
\text { (b) when and (c) who }\end{array}$ & $\begin{array}{l}\text { Individualised nutritional plan: (a) content and } \\
\text { (b) based on }\end{array}$ & $\begin{array}{l}\text { (a) Follow-up, (b) content in follow-up and } \\
\text { (c) who }\end{array}$ & $\begin{array}{l}\text { Oral } \\
\text { nutritional } \\
\text { supplement }\end{array}$ \\
\hline $\begin{array}{l}\text { 6. Pedersen et } \\
\text { al }{ }^{27} \text { Denmark }\end{array}$ & (a) Hospital & $\begin{array}{l}\text { (a) Three daily meals, three between-meal snacks, } \\
\text { supplements and instructions for implementing } \\
\text { the plan. Individual arrangements with the primary } \\
\text { healthcare provider; for example, concerning } \\
\text { nutritional support post-discharge, meal service, } \\
\text { food delivery and home care to supply daily } \\
\text { meals }\end{array}$ & $\begin{array}{l}\text { (a) Three home visits or counselling over } \\
\text { telephone 1, } 2 \text { and } 4 \text { weeks post-discharge. }\end{array}$ & Yes \\
\hline
\end{tabular}

$\begin{array}{ll}\text { (b) Before discharge } & \text { (b) Nutritional needs identified during hospital }\end{array}$ stay and tailored to the individual preferences and circumstances

(b) Nutritional counselling, patients' adherence o nutritional plan was assessed, identify inhibiting and restraining elements, motivation and adjusting the nutrition plan if needed.

(c) Clinical nurse specialist

(c) Clinical dietitian, attended by the patients' daily home care provider.

\begin{tabular}{|c|c|c|c|c|}
\hline \multirow[t]{3}{*}{$\begin{array}{l}\text { 7. Sharma et } \\
\left.a\right|^{25} \text { Australia }\end{array}$} & (a) Hospital & $\begin{array}{l}\text { (a) A combination of strategies based on the } \\
\text { individual patients' food preferences; for example, } \\
\text { mid-meal snack and food fortification. Intervention } \\
\text { where appropriate, aimed to meet } 100 \% \text { of } \\
\text { patients' energy and protein requirements for ideal } \\
\text { body weight. }\end{array}$ & (a) Monthly telephone call for 2 months. & Yes \\
\hline & $\begin{array}{l}\text { (b) } 24 \text { hours on receiving } \\
\text { referral from the research } \\
\text { dietitian }\end{array}$ & (b) Nutritional assessment & $\begin{array}{l}\text { (b) Compliance with the dietetic plan was } \\
\text { assessed, dietetic counselling, weight. In case } \\
\text { patients were discharged to a nursing home, the } \\
\text { dietitian contacted the nursing home manager } \\
\text { and forwarded the nutritional care plan to be } \\
\text { followed. }\end{array}$ & \\
\hline & (c) Ward dietitian & & (c) Research dietitian. & \\
\hline \multirow[t]{3}{*}{$\begin{array}{l}\text { 8. Terp et } a l^{42} \\
\text { Denmark }\end{array}$} & (a) Hospital & $\begin{array}{l}\text { (a) Advice on nutritional intake, everyday } \\
\text { food if relevant combined with oral nutritional } \\
\text { supplements. }\end{array}$ & $\begin{array}{l}\text { (a) Three follow-up visits } 1,4 \text { and } 8 \text { weeks post- } \\
\text { discharge. }\end{array}$ & Yes \\
\hline & (b) Before discharge & (b) Individual requirements and preferences & $\begin{array}{l}\text { (b) Monitoring the nutritional status, evaluation } \\
\text { of the dietary intake and identification and } \\
\text { management of problems related to inadequate } \\
\text { dietary intake. }\end{array}$ & \\
\hline & (c) Registered dietitian & & $\begin{array}{l}\text { (c) Nursing staff in municipality; the final } 3 \text { month } \\
\text { follow-up visit, was conducted by the geriatric } \\
\text { nurse from the hospital. }\end{array}$ & \\
\hline \multirow[t]{3}{*}{$\begin{array}{l}\text { 9. Yang et } a l^{43} \\
\text { Taiwan }\end{array}$} & (a) Hospital & $\begin{array}{l}\text { (a) Advice according to energy and protein intake } \\
\text { requirements. }\end{array}$ & $\begin{array}{l}\text { (a) Before discharge, a dietitian taught the post- } \\
\text { discharge diet and provided dietary advice. } \\
\text { Family caregivers participated in the dietary } \\
\text { counselling. Post-discharge phone calls were } \\
\text { adopted regularly. How often and how many } \\
\text { phone calls were not reported. }\end{array}$ & No \\
\hline & (b) Before discharge & (b) Nutritional status and physical activity & $\begin{array}{l}\text { (b) Tracking the nutritional intake status and } \\
\text { prescribing individualised nutritional plans. }\end{array}$ & \\
\hline & (c) Dietitian & & $\begin{array}{l}\text { (c) Trained data collectors from clinical staff. The } \\
\text { dietitian was in charge of anthropometry and } \\
\text { nutritional intake status. The blood parameters } \\
\text { were performed by the laboratory department. }\end{array}$ & \\
\hline
\end{tabular}

physiological resources, preferences, individual goals ${ }^{29}$ and economic status. The included studies considered diverse aspects of patients' situations when individualised nutritional care plans were performed. Additionally, the studies entailed different follow-ups. The observed effects of the interventions might be due to the type of follow-ups and/or content of the plans.

As noted, the reviewed studies measured 10 different outcomes. Most studies measured nutritional status ${ }^{19258-43}$ and re/hospitalisation. ${ }^{1925273842}$ A research gap was reflected in the lack of studies measuring cognitive outcomes. This review did not find any unambiguous answer to the research questions regarding whether interventions were effective and in what way they were effective.
Specifically, four studies indicated that the intervention had a significant effect on nutritional status, ${ }^{19} 384243$ and four studies demonstrated that the intervention did not. ${ }^{25} 39-41$ One study showed that the intervention had a significant effect on ADLs in one intervention group, ${ }^{41}$ and three studies did not. ${ }^{193842}$ One study revealed a significant effect on physical performance,${ }^{38}$ and three studies showed no such effect. ${ }^{19} 4142$ One study showed significant effect on readmission, ${ }^{27}$ and four studies showed no such effect. ${ }^{19} 253842$ All four studies that measured mortality ${ }^{19} 253842$ reported non-significant results, which may indicate that individual nutritional care plans do not reduce mortality. However, we did not include studies in which the intervention lasted longer than 3 months 
Table 3 Outcomes measured in the studies and the intervention effects

\begin{tabular}{|c|c|c|c|c|c|c|c|c|c|}
\hline & $\begin{array}{l}\text { Andersson } \\
\text { et } a l^{39}\end{array}$ & Beck et $a l^{12}$ & Beck et $a l^{19}$ & $\begin{array}{l}\text { Feldblum } \\
\text { et } a l^{\star 40}\end{array}$ & $\begin{array}{l}\text { Pedersen } \\
\text { et } a I^{41}\end{array}$ & $\begin{array}{l}\text { Pedersen et } \\
a l^{27}\end{array}$ & $\begin{array}{l}\text { Sharma et } \\
a l^{25}\end{array}$ & Terp et $a l^{42}$ & $\begin{array}{l}\text { Yang et } \\
a l^{\star 43}\end{array}$ \\
\hline 1. ADLs & & NS & NS & & $\begin{array}{l}\mathrm{S}(\mathrm{IG} 1) \mathrm{NS} \\
(\mathrm{IG} 2)\end{array}$ & & & NS & \\
\hline $\begin{array}{l}\text { 2. Physical } \\
\text { performance }\end{array}$ & & $\begin{array}{l}\text { S (mobility) } \\
\text { NS (handgrip } \\
\text { strength, } \\
\text { chair-stand } \\
\text { test) }\end{array}$ & $\begin{array}{l}\text { NS (mobility, } \\
\text { hand grip } \\
\text { strength) }\end{array}$ & & $\begin{array}{l}\text { NS } \\
\text { (handgrip } \\
\text { strength, } \\
\text { chair-stand } \\
\text { test, CAS) }\end{array}$ & & & $\begin{array}{l}\text { NS (handgrip } \\
\text { strength) }\end{array}$ & \\
\hline 3. Nutritional status & $\begin{array}{l}\text { NS } \\
\text { (appetite, } \\
\text { BMI) }\end{array}$ & $\begin{array}{l}\text { S (energy } \\
\text { intake, ONS } \\
\text { intake, protein } \\
\text { intake, weight) }\end{array}$ & $\begin{array}{l}\text { S (energy intake, } \\
\text { protein intake, } \\
\text { weight) }\end{array}$ & $\begin{array}{l}\text { NS (dietary } \\
\text { intake) }\end{array}$ & NS (MNA) & & $\begin{array}{l}\text { NS (BMI, } \\
\text { weight) }\end{array}$ & $\mathrm{S}$ (weight) & $\begin{array}{l}\text { S (BMI, } \\
\text { energy } \\
\text { intake) }\end{array}$ \\
\hline 4. QoL & NS & & NS & & NS & & NS & & \\
\hline $\begin{array}{l}\text { 5. Need of social } \\
\text { services }\end{array}$ & & NS & NS & & & & & & \\
\hline $\begin{array}{l}\text { 6. } \mathrm{Re} / \\
\text { hospitalisation }\end{array}$ & & $\begin{array}{l}\text { NS } \\
\text { (readmission) }\end{array}$ & NS (readmission) & & & $\begin{array}{l}\text { S } \\
\text { (readmission) }\end{array}$ & $\begin{array}{l}\text { S (length } \\
\text { of hospital } \\
\text { stay) NS } \\
\text { (readmission) }\end{array}$ & $\begin{array}{l}\text { NS } \\
\text { (readmission) }\end{array}$ & \\
\hline 7. Mortality & & NS & NS & & & & NS & NS & \\
\hline $\begin{array}{l}\text { 8. Depression } \\
\text { measures }\end{array}$ & & & & & NS & & & & \\
\hline $\begin{array}{l}\text { 9. Complications } \\
\text { during } \\
\text { hospitalisation }\end{array}$ & & & & & & & NS & & \\
\hline $\begin{array}{l}\text { 10. Self-rated } \\
\text { health }\end{array}$ & & & & & & & & $\mathrm{S}$ & \\
\hline
\end{tabular}

Need of social services=for example, home care, home nursing, meals-on-wheels.

Blank boxes indicate items not measured in the study.

*Two studies -Feldblum et al and Yang et al-lasted for 6 months. Only outcomes reported up to 3 months post-discharge were included in this scoping review. All significant results were improvements.

ADLs, activities of daily living; BMI, bodymass index; CAS, Cumulated Ambulation Score; IG, intervention group; MNA, Mini Nutritional Assessment;

NS, not significant; ONS, oral nutritional supplements; QoL, quality of life; S, significant.

post-discharge; to reduce mortality, interventions may need to last longer than 3 months.

In sum, this review yielded ambiguous results concerning four outcomes, which need to be further investigated. The different results, and whether they are significant, may be due to assessment tools, the number of participants or the study design.

We argue that there is a need for a systematic review and, if possible, a meta-analysis on this subject, and one that assesses study quality. We suggest the following potential hypothesis for a future systematic review: individualised nutritional care plans can reduce malnutrition during hospitalisation and up to 6 months post-discharge from hospital. The use of ONSs was important for the effect of an individualised plan.

\section{Limitations}

A limitation of this study may be the time limit-up to 3 months post-discharge. The lack of an outcome effect may be because the interventions were too short to provide any evidence of improvement. Three months' follow-up time may be insufficient for determining whether an intervention can reduce the risk of readmission or mortality rates.

\section{CONCLUSION}

No uniform definition of an individualised nutritional care plan was used in the studies. The individualised care plans were all developed based on an individual assessment of patients' nutritional needs, conditions and desires; although, the content of the individualised plans differed somewhat. In addition, to meet patients' nutritional needs, the individualised nutritional plan might include ONSs; meals-on-wheels and economic factors, such as inexpensive food sources and recipes. Our results suggest that individualised nutritional care plans and follow-up home visits may improve patients' nutritional status. However, only nine papers were included and these measured 10 different outcomes. This does not lend strength to any of the outcomes. This scoping review can inform future research; there remains a need for a systematic review to assess study quality and extend the time to 6 months post-discharge.

\section{Author affiliations}

${ }^{1}$ Faculty of Nursing and Health Sciences, Nord University, Levanger, Norway

${ }^{2}$ Faculty of Nursing and Health Sciences, Nord University, Bodø, Norway

${ }^{3}$ Medical Library, Aalborg University Hospital, Aalborg, Denmark 
${ }^{4}$ Danish Centre of Clinical Guidelines and Danish Centre of Systematic Reviews, A Joanna Briggs Institute Centre of Excellence, Aalborg University, Aalborg, Denmark

Contributors $\mathrm{KI}$ developed the research questions and methods and contributed substantially to drafting and editing. LU contributed to the methods, and edited and provided feedback throughout the writing process. IGK provided feedback throughout the writing process. CS and PP contributed to the development of the search strategy. PP contributed to developing the research questions and was a major contributor in review analysis. All authors read and approved the final version of this manuscript.

Funding KI, LU and IGK received funding from the Faculty of Nursing and Health Sciences, Nord University. CS and PP received funding from Aalborg University Hospital.

Competing interests None declared.

Patient consent for publication Not required.

Provenance and peer review Not commissioned; externally peer reviewed.

Data availability statement Data sharing not applicable as no datasets generated and/or analysed for this study. All data were obtained from publicly available materials.

Supplemental material This content has been supplied by the author(s). It has not been vetted by BMJ Publishing Group Limited (BMJ) and may not have been peer-reviewed. Any opinions or recommendations discussed are solely those of the author(s) and are not endorsed by BMJ. BMJ disclaims all liability and responsibility arising from any reliance placed on the content. Where the content includes any translated material, BMJ does not warrant the accuracy and reliability of the translations (including but not limited to local regulations, clinical guidelines, terminology, drug names and drug dosages), and is not responsible for any error and/or omissions arising from translation and adaptation or otherwise.

Open access This is an open access article distributed in accordance with the Creative Commons Attribution Non Commercial (CC BY-NC 4.0) license, which permits others to distribute, remix, adapt, build upon this work non-commercially, and license their derivative works on different terms, provided the original work is properly cited, appropriate credit is given, any changes made indicated, and the use is non-commercial. See: http://creativecommons.org/licenses/by-nc/4.0/.

\section{ORCID iD}

Kari Ingstad http://orcid.org/0000-0003-4608-2294

\section{REFERENCES}

1 Abd Aziz NAS, Teng NIMF, Abdul Hamid MR, et al. Assessing the nutritional status of hospitalized elderly. Clin Interv Aging 2017;12:1615-25.

2 Elia M, Russell CA, Stratton RJ. Malnutrition in the UK: policies to address the problem. Proc Nutr Soc 2010;69:470-6.

3 Meijers JMM, Schols JMGA, van Bokhorst-de van der Schueren MAE, et al. Malnutrition prevalence in the Netherlands: results of the annual Dutch national prevalence measurement of care problems. $\mathrm{Br}$ J Nutr 2009;101:417-23.

4 Rasheed S, Woods RT. Predictive validity of 'malnutrition universal screening tool' ('MUST') and short form mini nutritional assessment (MNA-SF) in terms of survival and length of hospital stay. Espen $J$ 2013;8:e44-50.

5 Allard JP, Keller H, Teterina A, et al. Factors associated with nutritional decline in hospitalised medical and surgical patients admitted for $7 \mathrm{D}$ or more: a prospective cohort study. Br J Nutr 2015;114:1612-22.

6 Allard JP, Keller H, Jeejeebhoy KN, et al. Malnutrition at hospital admission-contributors and effect on length of stay: a prospective cohort study from the Canadian malnutrition task force. JPEN J Parenter Enteral Nutr 2016;40:487-97.

7 Kondrup J, Sorensen JM. The magnitude of the problem of malnutrition in Europe. In: The economic, medical/scientific and regulatory aspects of clinical nutrition practice: What impacts what? Berlin: Karger Publishers, 2009.

8 Badgwell B, Stanley J, Chang GJ, et al. Comprehensive geriatric assessment of risk factors associated with adverse outcomes and resource utilization in cancer patients undergoing abdominal surgery. J Surg Oncol 2013;108:182-6.

9 Bell JJ, Pulle RC, Crouch AM, et al. Impact of malnutrition on 12-month mortality following acute hip fracture. ANZ J Surg 2016;86:157-61.
10 Caccialanza R, Klersy C, Cereda E, et al. Nutritional parameters associated with prolonged hospital stay among ambulatory adult patients. CMAJ 2010;182:1843-9.

11 Marshall S, Bauer J, Isenring $\mathrm{E}$. The consequences of malnutrition following discharge from rehabilitation to the community: a systematic review of current evidence in older adults. J Hum Nutr Diet 2014;27:133-41.

12 Stratton RJ, King CL, Stroud MA, et al. 'Malnutrition universal screening tool' predicts mortality and length of hospital stay in acutely ill elderly. Br J Nutr 2006;95:325-30.

13 Hestevik CH, Molin M, Debesay J, et al. Healthcare professionals experiences of providing individualized nutritional care for Older People in hospital and home care: a qualitative study. BMC Geriatr 2019;19:1-9.

14 Håkonsen SJ, Pedersen PU, Bjerrum M, et al. Nursing minimum data sets for documenting nutritional care for adults in primary healthcare: a scoping review. JBI Database Sys Rev Implement Rep 2018;16:117-39.

15 Otsuki I, Himuro N, Tatsumi H, et al. Individualized nutritional treatment for acute stroke patients with malnutrition risk improves functional independence measurement: a randomized controlled trial Geriatr Gerontol Int 2020;20:176-82.

16 Organisation for Economic Co-operation and Development. Health at a glance 2017: OECD indicators. Paris: OECD Publishing, 2017.

17 Organisation for Economic Co-operation and Development. Length of hospital stay (indicator), 2019. Available: https://data.oecd.org/ healthcare/length-of-hospital-stay.htm [Accessed 1 Aug 2019].

18 Beck AM, Holst M, Rasmussen $\mathrm{HH}$. Oral nutritional support of older (65 years+) medical and surgical patients after discharge from Hospital: systematic review and meta-analysis of randomized controlled trials. Clin Rehabil 2013;27:19-27.

19 Beck A, Andersen UT, Leedo E, et al. Does adding a dietician to the liaison team after discharge of geriatric patients improve nutritional outcome: a randomised controlled trial. Clin Rehabil 2015;29:1117-28.

20 Pedersen JL, Pedersen PU, Damsgaard EM. Nutritional follow-up after discharge of malnourished geriatric patients - design of a randomized clinical study. J Nutr Health Aging 2015;4:92-101.

21 Allen J, Hutchinson AM, Brown R, et al. User experience and care integration in transitional care for older people from hospital to home: a meta-synthesis. Qual Health Res 2017;27:24-36.

22 Munk T, Tolstrup U, Beck AM, et al. Individualised dietary counselling for nutritionally at-risk older patients following discharge from acute hospital to home: a systematic review and meta-analysis. J Hum Nutr Diet 2016;29:196-208.

23 Prvu Bettger J, Alexander KP, Dolor RJ, et al. Transitional care after hospitalization for acute stroke or myocardial infarction: a systematic review. Ann Intern Med 2012;157:407-16.

24 Keller H, Payette H, Laporte M, et al. Patient-reported dietetic care post hospital for free-living patients: a Canadian malnutrition task force study. J Hum Nutr Diet 2018;31:33-40.

25 Sharma $\mathrm{Y}$, Thompson $\mathrm{CH}$, Kaambwa B, et al. Investigation of the benefits of early malnutrition screening with telehealth follow up in elderly acute medical admissions. QJM 2017;110:639-47.

$26 \mathrm{Ha} \mathrm{L}$, Hauge T, Spenning AB, et al. Individual, nutritional support prevents undernutrition, increases muscle strength and improves QOL among elderly at nutritional risk hospitalized for acute stroke: a randomized, controlled trial. Clin Nutr 2010;29:567-73.

27 Lindegaard Pedersen J, Pedersen PU, Damsgaard EM. Nutritional follow-up after discharge prevents readmission to hospital - a randomized clinical trial. J Nutr Health Aging 2017;21:75-82.

28 Dorner B, Friedrich EK. Position of the Academy of nutrition and dietetics: individualized nutrition approaches for older adults: longterm care, post-acute care, and other settings. J Acad Nutr Diet 2018;118:724-35.

29 Volkert D, Beck AM, Cederholm T, et al. ESPEN guideline on clinical nutrition and hydration in geriatrics. Clin Nutr 2019;38:10-47.

30 New South Wales Nutrition Care. Policy directive. New South Wales government health, 2017. Available: https://intranet.nnswlhd.health. nsw.gov.au/docs/PD2017 041-nutrition-care-v-002.pdf [Accessed 2 Aug 2019].

31 Munn Z, Peters MDJ, Stern C, et al. Systematic review or scoping review? guidance for authors when choosing between a systematic or scoping review approach. BMC Med Res Methodol 2018;18:143.

32 Peters MD, Godfrey CM, Mclnerney P, et al. The Joanna Briggs Institute reviewers' manual 2015: methodology for JBI scoping reviews. Adelaide: JBI, 2015.

33 Ingstad K, Uhrenfeldt L, Kymre IG, et al. Scoping review protocol: effectiveness of individualised nutritional care plans to reduce malnutrition during hospitalisation and up to 3 months after discharge. BMJ Open 2019;9:e032615. 
34 Arksey H, O'Malley L. Scoping studies: towards a methodological framework. Int J Soc Res Methodol 2005;8:19-32.

35 Levac D, Colquhoun H, O'Brien KK. Scoping studies: advancing the methodology. Implementation Sci 2010;5:69.

36 The Joanna Briggs Institute. Joanna Briggs Institute Reviewers' manual: 2017 edition, 2017. Available: https://reviewersmanual. joannabriggs.org/ [Accessed 3 Jan 2019].

37 Tricco AC, Lillie E, Zarin W, et al. PRISMA extension for scoping reviews (PRISMA-ScR): checklist and explanation. Ann Intern Med 2018;169:467-73.

38 Beck AM, Kjær S, Hansen BS, et al. Follow-up home visits with registered dietitians have a positive effect on the functional and nutritional status of geriatric medical patients after discharge: a randomized controlled trial. Clin Rehabil 2013;27:483-93.

39 Andersson J, Hulander E, Rothenberg E, et al. Effect on body weight, quality of life and appetite following individualized, nutritional counselling to home-living elderly after rehabilitation - an open randomized trial. J Nutr Health Aging 2017;21:811-8.

40 Feldblum I, German L, Castel H, et al. Individualized nutritional intervention during and after hospitalization: the nutrition intervention study clinical trial. J Am Geriatr Soc 2011;59:10-17.
41 Pedersen JL, Pedersen PU, Damsgaard EM. Early nutritional follow-up after discharge prevents deterioration of $A D L$ functions in malnourished, independent, geriatric patients who live alone - a randomized clinical trial. J Nutr Health Aging 2016;20:845-53.

42 Terp R, Jacobsen KO, Kannegaard P, et al. A nutritional intervention program improves the nutritional status of geriatric patients at nutritional risk-a randomized controlled trial. Clin Rehabil 2018;32:930-41.

43 Yang P-H, Lin M-C, Liu Y-Y, et al. Effect of nutritional intervention programs on nutritional status and readmission rate in malnourished older adults with pneumonia: a randomized control trial. Int J Environ Res Public Health 2019;16:E4758.

44 Uhrenfeldt L, Sørensen EE, Bahnsen IB, et al. The centrality of the nurse-patient relationship: a Scandinavian perspective. J Clin Nurs 2018;27:3197-204.

45 Storm M, Coulter A. Patient-centred care in the Nordic countries. In: Schibevaag KA, ed. Researching patient safety and quality in healthcare: a Nordic perspective. London and New York: CRC Press Taylor \& Francis Group, 2017: 27-42.

46 Moher D, Liberati A, Tetzlaff J, et al. Preferred reporting items for systematic reviews and meta-analyses: the PRISMA statement. PLoS Med 2009;6:e1000097. 